\title{
Trachoma prevalence among schoolchildren in the municipality of Turmalina, Minas Gerais state
}

\author{
Prevalência de Tracoma em crianças em idade \\ escolar no município de Turmalina, $M G$
}

Evanildo José da Silva1', Layze Alves Vieira Oliveira1', Luciano Sólia Nasser², Luciana Fernandes Amaro Leite', Antônio Prates Caldeira², Leida Calegário de Oliveira ${ }^{1}$

\begin{abstract}
Trachoma has been mistakenly assumed as having been eradicated, but is on the list of neglected diseases. It is the leading cause of preventable blindness in the world, being found predominantly in developing countries. Several studies have shown that this disease is currently present in all regions of Brazil, which shows that both the government (at the federal, state and municipal levels) and academia must continue to treat trachoma as one of the causes of blindness. In this study, we sought to identify the prevalence of trachoma among schoolchildren aged between seven and 15 years from public schools in the municipality of Turmalina, Minas Gerais state. The survey was conducted in this municipality, located in the Jequitinhonha Valley, a region that contains populations who live in situations of high social vulnerability, and thus display the characteristics that are conducive to the emergence of the disease. The participants were six doctors and 11 nurses working in primary healthcare, trained and standardized to do so. Health professionals examined 635 students aged 7-15 years in the public schools of Turmalina. Students with a clinical diagnosis of trachoma underwent conjunctiva scraping with a swab and the material was sent for laboratory analysis. All school children diagnosed with trachoma were treated at the Unified Health System (SUS). The collected data were analyzed using the Statistical Package for Social Sciences software, IBM Inc., USA - SPSS, version 22.0. Among the students, a 4.7\% prevalence rate of trachoma was found, predominantly in rural areas.
\end{abstract}

Keywords: Trachoma; Prevalence; Students; Blindness

\section{ReSUMO}

O tracoma, tido equivocadamente como erradicado em nosso meio, encontra-se na lista de doenças negligenciadas. Trata-se da maior causa de cegueira evitável do mundo, sendo encontrado predominantemente nos países subdesenvolvidos. Diversos trabalhos têm demonstrado que esta doença atualmente se faz presente em todas as regiões do Brasil, o que evidencia que tanto o governo (nas esferas federal, estadual e municipal), quanto a academia devem continuar a considerar o tracoma entre as causas de cegueira em nosso meio. Neste trabalho, procurou-se levantar a prevalência de tracoma entre as crianças de sete a quinze anos matriculadas nas escolas da rede pública do município de Turmalina, MG. A pesquisa foi realizada neste município, situado no Vale do Jequitinhonha, considerando que existem nele regiões com populações em situação de alta vulnerabilidade social, portanto com características propícias para o surgimento da doença. Participaram da pesquisa seis médicos e onze enfermeiros com atuação na atenção primária, capacitados e padronizados para tal. Os profissionais de saúde realizaram o exame de 635 estudantes entre 7 a 15 anos nas escolas públicas de Turmalina, MG. Os estudantes com diagnóstico clínico de tracoma foram submetidos à raspagem de conjuntiva com swab e o material enviado para análise laboratorial. Todos os estudantes diagnosticados com tracoma foram tratados no Sistema Único de Saúde (SUS). Os dados coletados foram analisados com auxílio do software Statistical Package for Social Sciences, IBM Inc., USA SPSS, versão 22.0. Entre os estudantes foi encontrada uma prevalência do tracoma de 4,7\%, com predomínio nas áreas rurais.

Descritores: Tracoma; Prevalência; Estudantes; Cegueira

\footnotetext{
${ }^{1}$ Universidade Federal dos Vales do Jequitinhonha e Mucuri, Diamantina, MG, Brasil.

${ }^{2}$ Universidade Estadual de Montes Claros, Montes Claros, MG, Brasil.

The authors declare no conflicts of interests.

Received for publication 26/11/2015 - Accepted for publication 21/03/2016.
} 


\section{INTRODUCTION}

B eing the leading infectious cause of preventable blindness in the world, trachoma has as the etiological agent the bacteria $C$. trachomatis and is manifested as a chronic recurrent inflammation of the conjunctiva and cornea, causing scar tissue changes that can lead to the formation of entropion (inverted eyelid), trichiasis (inverted eyelashes) and corneal opacity, and may lead to blindness ${ }^{(1-5)}$. Trachoma occurs in various regions of the globe, including Latin America ${ }^{(6,7)}$. According to the World Health Organization (WHO), in 2011 there were approximately 325 million people living in endemic areas for trachoma worldwide, but only in Europe no case of blindness from this disease was evidenced ${ }^{(8)}$. The WHO recommends the SAFE strategy ( $\mathrm{S}=$ surgery, $\mathrm{A}=$ antibiotic, $\mathrm{F}=$ facial hygiene and $\mathrm{E}=$ environmental care) as a way to eliminate blindness by trachoma until $2020^{(9)}$. According to the WHO, the disease is considered under control when the prevalence is less than $5 \%^{(10)}$.

The transmission of trachoma occurs mainly directly from person to person through contact with eye secretions, and secondarily indirectly through contaminated objects such as: towels, sheets and pillowcases. According to Thylefors et al. (5), trachoma has five classical forms: two of them represent the inflammatory phase when there may be transmission of the disease, and the other three are sequelae forms when there is no transmission. The two types of inflammatory forms are: Trachomatous follicular inflammation (TFI) and Intense Trachomatous Inflammation (TI). The three sequelae forms are: Conjunctival Trachomatous Scarring (TS), Trachomatous Trichiasis (TT) and Corneal Opacification (CO). The symptoms are nonspecific and may vary from asymptomatic cases to tearing, foreign body sensation, discrete photophobia and pruritus. Patients presenting with entropion and/or trichiasis and/or with corneal ulcerations may complain of pain and photophobia. Blindness can occur due to the corneal scars caused by ulcers generated by trichiasis ${ }^{(1,5)}$. The diagnosis the trachoma is essentially clinical and usually made by external ocular examination using a binocular loupe from 2.0 to 3.0 times higher ${ }^{(1,5)}$. It must be established when there are at least two of the following clinical signs: follicles in the upper tarsal conjunctiva, follicles in the limb, typical conjunctival scarring (can be vertical and or horizontal), pannus in the upper limb (invasion of newly formed blood vessels). The differential diagnosis of trachoma must be carried out with the other follicular conjunctivitis as: folliculitis, toxic follicular conjunctivitis and acute and chronic follicular conjunctivitis of any etiology (eg. herpes simplex, adenovirus, molluscum contagiosum, adult inclusion conjunctivitis) ${ }^{(1,3,4)}$. The laboratory research is only indicated for the circulation of the etiologic agent in the community, and not for confirmation of cases and should be carried out in practice by the technique of direct immunofluorescence, which has high specificity and low ${ }^{(1,11)}$. Currently, the treatment by the effectiveness and practicality is done with the antibiotic Azithromycin $(20 \mathrm{mg} / \mathrm{kg})$ in a single dose, as contained in Ordinance No. 67 of 12/22/2005 of the Ministry of health (MS) ${ }^{(12)}$.

This survey was conducted in the municipality of Turmalina, MG. This city is part of the Jequitinhonha Valley, site of this study, where there is a lack of knowledge about the prevalence of this disease, since there is no research to describe the occurrence of trachoma in the region. Most of the city population in this region is socially vulnerable, with the proper characteristics for the spread of the disease. It is expected that the data collected can be a way to guide the adoption of public policies for the region. The present study comes against the current recommendations of the WHO and the Brazilian Ministry of health (MS) to guide the active search for trachoma in schoolchildren ${ }^{(1,8)}$.

\section{Objective}

Establish the prevalence of trachoma among schoolchildren from seven to fifteen years of public state and municipal schools in Turmalina, MG.

\section{MethodS}

It is a study in which we used the descriptive, analytical and cross-sectional approaches, and sampling was made by conglomerates.

The work was developed in the municipality of Turmalina, in the Jequitinhonha Valley, MG. This city, according to data from Instituto Brasileiro de Geografia e Estatística - IBGE ${ }^{(13)}$, had 18055 inhabitants in 2010, and $12926(71.6 \%)$ of them lived in urban area. The female population was 8887 (49.2\%), and male $9168(50.8 \%)$. It is estimated that the population in 2014 is approximately 19288 inhabitants. The Human Development Index (HDI) in this city was 0.682 , a value considered average within the five ranges defined: very low, low, average, high and very high ${ }^{(13)}$.

The research consisted in the clinical examination of primary and secondary school students from public (State and municipal) schools of Turmalina, MG, aged between 7 and 15 years, and it was performed by five doctors and eleven family nurses working in the City's primary care using a 2.5-diopter lighted magnifying glass. All professionals were previously trained and standardized for that. A sample was set, and the calculation was performed using the following parameters:

Confidence interval: 99\%;

Estimation error acceptable: $1.7 \%$.

For the $99 \%$ confidence interval, the critical value associated to the degree of confidence in the sample $\left(\mathrm{z}_{\mathrm{a}}\right)$ is 2.575 .

Due to not knowing the prevalence of trachoma among the population from seven to fifteen years in the city of Turmalina, MG, the prevalence of $4.8 \%$ was used, which corresponds to the average found in MG in the last survey. Thus, the sample size calculated was 604 students. However, in order to compensate for possible losses of participants throughout the work development, we added $5 \%$ to the number of subjects. Thus, the number used was 635 students.

Medical professionals, nurses and students of elementary school were part of the present survey.

The students were examined at the schools, in classrooms made available exclusively for this purpose. The data obtained was used to estimate the prevalence of the disease in students from the age group between seven and fifteen years in the city of Turmalina, MG.

The individuals diagnosed had biological material collected for direct immunofluorescence according to the following protocol ${ }^{(1)}$ :

- removal of tears and secretions from the eyes of the subject with the use of gauze, cleaning up the site with physiological saline.

- eversion of the upper eyelid.

- rubbing the swab firmly on the superior tarsal plate from the outer corner to the inner one and vice versa (10 times) rolling the swab. 
- positioning the swab on the slide.

- rolling the swab on the slide, drawing a virtual circle and ensuring that the entire surface of the swab has come into contact with the circle.

- wait for five minutes so that the culture dris on the slide.

- fixation of the tissue deposited using methanol.

-waiting for drying and stowing in styrofoam with ice temporarily.

- storage at a temperature of $-20^{\circ} \mathrm{C}$ until shipment to the Clinical Laboratory.

The biological material collected was sent to a Clinical Laboratory (Laboratório de Análises Clínicas Oswaldo Cruz) in Diamantina, where the direct immunofluorescence test was performed for the detection of $C$. trachomatis. This procedure was carried out only to confirm the presence of the bacteria in the population, once the diagnosis of trachoma is clinical ${ }^{(11)}$. In order to contain the spread of the disease, the family members of subjects diagnosed with trachoma were contacted and subjected to examination.

The data collected was analyzed by the Statistical Package for Social Sciences, IBM Inc., USA - SPSS, version 22.0. Descriptive statistical analyses were conducted to obtain the mean, standard deviation, absolute and relative frequencies of the data.

The authorization for the development of the research was given by the approval of the project and its instruments by the Research Ethics Committee (CEP) of Universidade Federal dos Vales do Jequitinhonha e Mucuri (UFVJM), and the signature of the informed consent (TCLE) by the participants, as well as by their legal guardians (in the case of schoolchildren), who spontaneously agreed to participate in the research after explanation of the project.

\section{RESULTS}

The tables below describe the results found in the search.

Table 1

Distribution of participant students in relation to gender, origin and involvement by trachoma, Turmalina, MG, $2014(n=635)$

\begin{tabular}{lll}
\hline Variable & $\mathbf{N}$ & $\%$ \\
\hline Gender & & \\
$\quad$ Female & 357 & 56,2 \\
$\quad$ Male & 278 & 43,8 \\
Origin & & \\
Urban area & 391 & 61,6 \\
Countryside & 244 & 38,4 \\
Trachoma & & \\
$\quad$ Absent & 605 & 95,3 \\
$\quad$ Present & 30 & 4,7 \\
Subtype of Trachoma (n=30) & & \\
$\quad$ Intense inflammatory trachoma & 0 & 0,0 \\
$\quad$ Follicular inflammatory trachom & 30 & 100,0 \\
$\quad$ Trachomatous Trichiasis & 0 & 0,0 \\
$\quad$ Conjunctival trachomatous scarring & 0 & 0,0 \\
$\quad$ Corneal opacity & 0 & 0,0 \\
& & \\
\hline
\end{tabular}

Table 2

\section{Distribution of cases of trachoma according to gender and origin of students, Turmalina, MG, 2014}

\begin{tabular}{|c|c|c|c|}
\hline Variable & Trachoma & & \\
\hline & Yes & No & P-value* \\
\hline & n (\%) & n (\%) & \\
\hline \multicolumn{4}{|l|}{ Gender } \\
\hline Male & $11(36,7)$ & $267(44,1)$ & 0,421 \\
\hline Female & $19(63,3)$ & $338(55,9)$ & \\
\hline \multicolumn{4}{|l|}{ Origin } \\
\hline Urban area & $9(30,0)$ & $382(63,1)$ & $<0,001$ \\
\hline Countryside & $21(70,0)$ & $223(36,9)$ & \\
\hline
\end{tabular}

* teste $\mathrm{X}^{2}$

Source: research data

\section{Discussion}

Table 1 shows the distribution of schoolchildren who were examined in this study in relation to gender, origin and involvement by trachoma. The analysis allows us to note that the largest portion of these children was of females and from the urban area $(61.6 \%)$ from the city of Turmalina, MG. Of the total 635 children examined, 30 were diagnosed with trachoma. Thus, the prevalence of this disease in the study population was $4.7 \%$. Comparatively, Koizumi et al. ${ }^{(14)}$, in a study carried out in São Paulo (SP), demonstrated a prevalence of $2.2 \%$ in this city, while Caninéo et al. ${ }^{(14)}$, in a study carried out in Embu das Artes - SP, found a rate of $3.1 \%$. On the other hand, a household survey carried out with children in the community of Vila Estrutural, a former invasion area in the Brazilian Federal District and under precarious conditions of sanitation, demonstrated a prevalence of $12.5 \%{ }^{(15)}$, wheras in the studies of Lucena et al. ${ }^{(16)}$ in Porteira (CE), a rate of $26.2 \%$ was observed. Lopes et al. ${ }^{(17)}$ found cases of trachoma in all Brazilian States, but reported an average prevalence of $6.1 \%$ in Santa Catarina, $4.6 \%$ in Rio Grande do Sul and $4.5 \%$ in Roraima. According to these authors, in MG the average prevalence was $4.8 \%$. The studies of Paula et al. ${ }^{(18)}$ showed a prevalence rate of $30.3 \%$ among inhabitants of the indigenous communities in Amazonas.

These findings confirm that although there is great variability in the prevalence among the various locations in Brazil, this disease is found in all regions of Brazil, which demands attention in relation to the diagnosis by health professionals and Health Departments of all Brazilian States. Special attention should be given to the health of indigenous people, since due to generally poor hygiene and socioeconomic conditions, the possibility for high rates of trachoma is considerable.

Among schoolchildren diagnosed with the disease in this study, a percentage of $100 \%$ children with Follicular Inflammatory Trachoma was found, and no cases of Intense Inflammatory Trachoma were identified (Table 1). The present study did not detect sequelae forms of the disease, finding similar to that found in most studies carried out in Brazil, as these are more common in elderly people after several re-infestation, which occurs more frequently in endemic areas. Lopes et al. ${ }^{(17)}$, in a study from 2002 to 2007 with 119,531 Brazilian schoolchildren from all regions, found an average prevalence of trachoma of $5.0 \%$, being $4.9 \%$ of TF, $0.03 \%$ of TI and $0.05 \%$ of TS. Caninéo et al. ${ }^{(14)}$, while examining 2,374 schoolchidren in the city of Embu das Artes - 
SP, found a prevalence of $3.1 \%$, not finding the TI form nor sequelae forms of the disease. Ferraz et al. ${ }^{(19)}$, studying 1,749 schoolchildren in Bauru (SP), found a prevalence of $3.8 \%$, being $3.7 \%$ of TF and $0.06 \%$ of TI, not finding cases with sequelae forms. The study carried out by Lucena et al. ${ }^{(16)}$ in the village of Serrolândia, city of Ipubi, in Chapada do Araripe (CE), considered an endemic zone of trachoma, showed a prevalence of $20.5 \%$, being $8.6 \%$ of TF; $0.2 \%$; of TI, $11.2 \%$ of TS and $0.1 \%$ of TT; with no cases of CO being found. It is important to note that all children diagnosed with trachoma in the present study were treated by SUS and followed in specialized ambulatory of the municipal public services.

Table 2 shows the distribution of trachoma cases in relation to gender and also the origin of the people affected. No statistically significant difference was found between trachoma and gender, showing that the disease has equally affected boys and girls in the study population. The table analysis also shows that there was no association between trachoma and origin of schoolchildren, thus demonstrating that a greater number of cases was observed in the population living in the countryside of Turmalina MG, where the socioeconomic and sanitation conditions are more precarious.

The Pan American Health Organization (PAHO) ${ }^{(20)}$ considers trachoma as one of their priorities, aiming to eradicate blindness due to this cause. However, there are many difficulties in Brazil to reach this goal, among them:

- wide spread of trachoma in the country;

- great territorial extension of the country;

- epidemiological and socioeconomic diversity in the country;

- difficulty of access to populations in need and the more remote areas, such as rural and indigenous communities;

- lack of prioritization of the problem by the managers of the SUS;

- lack of coordination with primary health care;

- lack of coordination with the educational sector; and

- lack of knowledge about the disease by health professionals.

Due to so many obstacles, trainings shall be conducted within a broader context of lifelong learning as a strategy to give primary care professionals knowledge in relation to trachoma, as they are in the front of SUS. A prioritization of this issue by the managers of SUS is expected, so that Brazil can effectively overcome this issue in all regions.

\section{Conclusion}

Trachoma is prevalent among students between seven to fifteen years old enrolled in State and municipal public schools in Turmalina, MG, and according to the WHO criteria the disease is under control. Trachoma equally affects children of both genders, but it was more frequent in those living in the countryside, where the socio-economic and sanitation conditions are more precarious. The bacterium C. trachomatis is present among the population of Turmalina, MG. The identification of cases of active trachoma in schoolchildren in State and municipal public schools of Turmalina, Minas Gerais, suggests the need for further studies. Future research with the families members of the schoolchildren affected should be carried out, including issues such as education, housing conditions and economic situation, aiming at a better knowledge and control of the disease in this city.

\section{ReFERENCES}

1. Brasil. Ministério da Saúde. Fundação Nacional de Saúde. Manual de controle do tracoma. Brasília (DF): Ministério da Saúde; 2014. 54p.

2. Schellin SA, Sousa RL. Tracoma: ainda uma importante causa de cegueira. Rev Bras Oftalmol. 2012; 71(3):199-204.

3. Yanoff M, Duker J. Oftalmologia. 3a ed. Rio de Janeiro: Elsevier; 2011.

4. Riordan-Eva P, Whitcher JP. Oftalmologia geral de Vaughan \& Asbury. 17a ed. Porto Alegre: Artmed; 2011.

5. Thylefors B, Dawson C R, Jones BR, West SK, Taylor HR . A simple system for the assessment of trachoma and its complications. Bull World Health Organization. 1987; 65(4):477-83.

6. Mariotti SP, Pascolini D, Rose-Nussbauner J. Trachoma: global magnitude of a preventable cause of blindness. Br J Ophthalmol. 2009; 93(5): 563-8.

7. Polack S, Brooker S, Kuper H, Mariotti S, Mabey D, Foster A. Mapping the global distribution of trachoma. Bull World Health Organization. 2005; 83(1): 913-19.

8. World Health Organization (WHO). Global Alliance for the Elimination WHO, Primary health care level management of on of blinding trachoma by 2020. Weekly Epidemiol Rec. 2012; 87(17):161-8.

9. World Health Organization (WHO). Planning for the global elimination of trachoma (GET): report of a WHO Consultation. Geneva: WHO; 1997.

10. Solomom AW, Zondervan M, Kuper H, Buchan JC, Mabey DC, Foster A. Trachoma control: a guide for programme manager. Geneva: WHO; 2005.

11. Medina NH, Gentil RM, Caraça M, Suzuki CK, Melles HH. Análise de exames de imunofluorescência direta para o diagnóstico de tracoma. Rev Saúde Pública. 1996; 30(2):135-40.

12. Brasil. Gabinete do Ministério. Portaria ${ }^{\circ}$ 67, de 22 de Dezembro de 2005. Dispõe sobrea inclusão da Azitromicina no tratamento sistêmico de tracoma. Diário Oficial da União da República Federativa do Brasil. Brasília; 2005 Dez 26.

13. Brasil. Instituto Brasileiro de Geografia e Estatística. Senso 2010 Brasília: IBGE; 2010.

14. Caninéo PA, Nishimura S, Medina NH, Koizumi IK, Cardoso MR. Inquérito epidemiológico de tracoma em escolares no município de Embu das Artes - SP. Arq Bras Oftalmol. 2012; 75(1): 264-6.

15. Jesus HS, Lobo AP, Bordalo FS, Villar GB, Oliveira JC, Dias JA, et al . Inquérito domiciliar de prevalência de tracoma em crianças do Distrito Federal, Brasil. Cad Saúde Coletiva. 2013; 21(3): 318-24.

16. Lucena AR, Cruz AA, Akaishi P. Estudo epidemiológico do tracoma em comunidade da Chapada do Araripe - CE. Arq Bras Oftlamol. 2010; 73(3):271-5.

17. Lopes MF, Luna EJ, Medina NH, Cardoso MR, Freitas HS, Koizumi IK, et al. Prevalência de tracoma entre escolares brasileiros. Rev Saúde Pública. 2013; 47(3): 451-9.

18. Paula JS, Medina NH, Cruz AA. Trachoma among the Yanomami Indians. Braz J Med Biol Res. 2002; 35(10):1153-7.

19. Ferraz LC, Schellini SA, Padovani CR, Medina NH, Dalben I. Tracoma em crianças do ensino fundamental no município de Bauru - Estado de São Paulo. Brasil. Arq Bras Oftlamol. 2010; 73(5):433-7.

20. Organização Panamericana de Saúde. Eliminación del tracoma em las Américas. Bogotá: Primera Reunion Regional de los Gerentes De Programas; 2011. 